\title{
Beneficial effect of dietary Ephedra sinica on obesity and glucose intolerance in high-fat diet-fed mice
}

\author{
MOON-KOO SONG ${ }^{1}$, JAE-YOUNG UM ${ }^{2}$, HYEUNG-JIN JANG ${ }^{3}$ and BYUNG-CHEOL LEE ${ }^{1}$ \\ Departments of ${ }^{1}$ Internal Medicine, ${ }^{2}$ Pharmacology, and ${ }^{3}$ Biochemistry, \\ College of Oriental Medicine, Kyung Hee University, Seoul, Republic of Korea
}

Received November 10, 2011; Accepted December 30, 2011

DOI: $10.3892 /$ etm.2012.462

\begin{abstract}
Obesity is a major contributor to both glucose intolerance and metabolic syndrome. In this study, we investigated the anti-obesity and anti-hyperglycemic effects of Ephedra sinica on high-fat diet-fed mice. Male ICR mice were divided into four groups; the normal group, the obese and diabetic control group treated with a high-fat diet, the positive control group treated with a high-fat diet containing acarbose, and the experimental group treated with a high-fat diet containing Ephedra sinica. The effects of Ephedra sinica on obesity and glucose intolerance were measured by an oral glucose tolerance test (OGTT), plasma biochemistry, body and epididymal fat weight; the expression of adiponectin, peroxisome-proliferator-activated receptor $\alpha$ (PPAR- $\alpha$ ), tumor necrosis factor $\alpha(\mathrm{TNF}-\alpha)$ and leptin was also determined. Ephedra sinica reduced weight gain and epididymal fat accumulation, improved glucose intolerance on the OGTT, decreased triglycerides and increased high-density lipoprotein cholesterol compared to the controls. Moreover, it reduced weight gain and fasting glucose levels and improved HDL-cholesterol levels more than acarbose. Gene expression analysis revealed that Ephedra sinica upregulated the expression of adiponectin and PPAR- $\alpha$, and downregulated the expression of TNF- $\alpha$. From these results, we suggest that Ephedra sinica may reduce obesity and hyperglycemia by increasing PPAR- $\alpha$ and adiponectin and reducing TNF- $\alpha$, and that it may have the potential to be used clinically as an ingredient in food or drugs effective in obesity-related glucose intolerance treatments.
\end{abstract}

\section{Introduction}

In recent years, obesity and type 2 diabetes have become the most common human health problems worldwide (1). Obesity is a well-established risk factor for many chronic diseases,

Correspondence to: Dr Byung-Cheol Lee, Department of Internal Medicine, College of Oriental Medicine, Kyung Hee University, 1 Hoegi-dong, Dongdaemun-Ku, Seoul 130-702, Republic of Korea E-mail: hydrolee@korea.com

Key words: Ephedra sinica, obesity, glucose intolerance such as hyperinsulinemia, hypertension, abnormalities in lipid metabolism, glucose intolerance and type 2 diabetes $(2,3)$.

The contribution of obesity to type 2 diabetes may be due to the dysregulation of adipocytokines which are synthesized and secreted by adipose tissue. Adipose tissue secretes several major hormones, most notably adiponectin and leptin. Adiponectin is synthesized only in adipose tissue and is known to modulate insulin and appears to have an anti-inflammatory effect by inhibiting phagocytic activity and production of tumor necrosis factor $\alpha$ (TNF- $\alpha)$ in macrophages. The major role of leptin is that of a central regulator of adiposity (4). TNF- $\alpha$ is overproduced by adipose tissue and causes inflammation and, therefore, systemic insulin resistance by interfering with the insulin signaling cascade (5). These metabolic disorders are regulated by peroxisome proliferator-activated receptor $\alpha$ (PPAR- $\alpha$ ), which controls fatty acid oxidation, lipid and lipoprotein metabolism and inflammatory responses (6).

Ephedra sinica (Ma Huang) has been established for thousands of years in traditional uses in Korea and China (7). Ephedra sinica has been found to have sympathomimetic, antiinflammatory, hypoglycemic and antitussive/antiasthmatic effects (7). There have been reports that the use of Ephedra promotes weight loss in selected populations (8). In healthy overweight and obese populations Ephedra decreased body weight, fasting glucose levels and insulin levels (9). These findings indicate that Ephedra decreases the risks of glucose intolerance and obesity $(8,9)$. However, there has been no study concerning the anti-obesity and anti-hyperglycemic effects of Ephedra and its related mechanism in diet-induced obesityrelated type 2 diabetes.

In this study, we evaluated the influence of Ephedra sinica on body weight, epididymal fat weight, glucose metabolism, lipid metabolism, liver function, and the expression of PPAR- $\alpha$, leptin, adiponectin and TNF- $\alpha$ of adipose tissue, in obese type 2 diabetic mice under normal and high-fat feeding conditions.

\section{Materials and methods}

Preparation of Ephedra aqueous extracts. Ephedra sinica was obtained from the Department of Pharmaceutical Preparation of Oriental Medicine, Oriental Medical Hospital, Kyung Hee University, Seoul, Korea. Drug quality was tested according to the standards of the Korea Food and Drug Administration 
and those of our hospital. The dried Ephedra sinica $(1,000 \mathrm{~g})$ was added to ethanol $(1,500 \mathrm{ml}, 80 \%)$ and boiled for $2 \mathrm{~h}$ at $100^{\circ} \mathrm{C}$ using a heating mantle. The sieve-filtrated solvents were concentrated with a rotary evaporator (Model NE-1; EYELA Co., Japan) and dried with a freeze dryer (Model FD-1, EYELA Co.). Those extracts were added to distilled water $(1 \mathrm{~g} / 10 \mathrm{ml})$ and boiled for $2 \mathrm{~h}$ at $95^{\circ} \mathrm{C}$. The boiled solution was centrifuged at $14,000 \mathrm{rpm}$ for $20 \mathrm{~min}$ and the supernatant was obtained. After filtering through a $0.2-\mu \mathrm{m}$ filter, the extracts were kept at $-70^{\circ} \mathrm{C}$ for assay experiments.

Experimental design and animals. Male ICR mice (2-months old) weighing $30 \pm 5 \mathrm{~g}$ were purchased from the Central Lab. Animal Inc. (Seoul, Korea) and were housed in stainless- steel cages in an air-conditioned room controlled at $22 \pm 1^{\circ} \mathrm{C}$ and at $40-70 \%$ relative humidity under a 12:12 h dark:light schedule. Animals freely received diet and water for 1 week. After adapting to the lighting conditions for that 1 week, the mice were divided into four groups according to body weight. The normal group continued to be fed a normal diet ad libitum. High-fat diet (Surwit's Rodent Diet, product \#D12331, \% kcal; carbohydrate:protein:fat $=25.5: 16.5: 58.0$ ) was administered to the other three groups for 6 weeks. The diet for the Ephedra group contained 5\% Ephedra and the diet for the acarbose group (positive control) contained $0.5 \%$ acarbose. The body weight of each mouse was measured once a week and the total amount of food consumption was recorded every day using an electronic scale (CAS 2.5D, Korea). To minimize the error caused by animal movement, the mouse was put in a plastic bowl and measured while resting. After 6 weeks, the mice were sacrificed and the epididymal fat pad weight was recorded using an electronic scale. All experiments were carried out according to the protocols approved by the Animal Care Committee of the Animal Center at Kyung Hee University and in accordance with the principles outlined in the NIH Guide for the Care and Use of Laboratory Animals.

Oral glucose tolerance test and blood analysis. The concentration of fasting glucose was monitored at baseline, week 3 and week 6 after $8 \mathrm{~h}$ of fasting. Furthermore, an oral glucose tolerance test (OGTT) was carried out at the 6th week. Glucose was added to distilled water $(1.3 \mathrm{~g} / 2 \mathrm{ml})$ and administered to each mouse $(0.1 \mathrm{ml})$ through a stomach tube after $8 \mathrm{~h}$ of fasting. Blood glucose was determined at 0,30 and $60 \mathrm{~min}$ after administration. Blood was collected from the tail vein of each mouse. To measure the lipid profiles and liver functions, blood was collected from the hearts, while the mice were under anesthesia with diethyl ether. The blood was centrifuged at $3,000 \mathrm{rpm}$ for $20 \mathrm{~min}$ to obtain plasma. These samples were frozen at $-40^{\circ} \mathrm{C}$ until used in the analysis. Aspartate transaminase (AST), alanine transaminase (ALT), total cholesterol, HDL-cholesterol, LDL-cholesterol and triglyceride levels were measured.

RNA isolation. Total RNA was extracted from epididymal fat pads using a Mini RNA Isolation II $^{\mathrm{TM}}$ (Zymo Research, CA, USA) according to the manufacturer's instructions. After 6 weeks, the mice were sacrificed and the epididymal fat pad was quickly removed, placed in a tube (15 $\mathrm{mg}$ in each group), and ZR RNA buffer (300 $\mu \mathrm{l})$ was added. These samples were

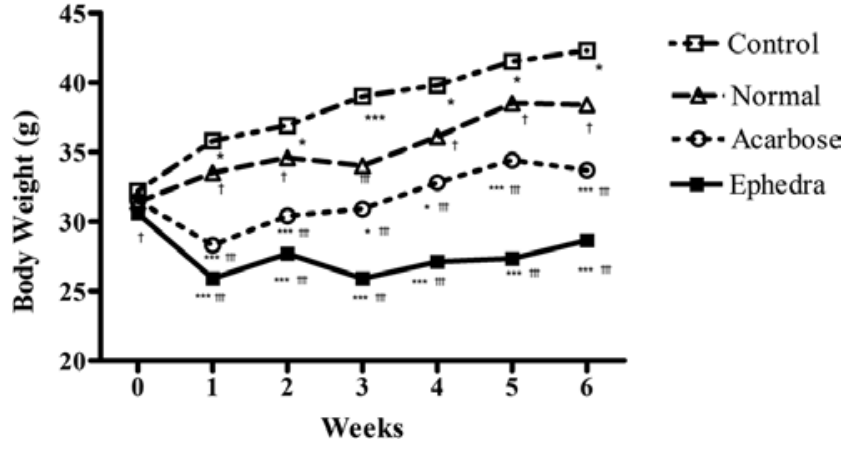

Figure 1. Effect of Ephedra sinica on body weight gain in obese diabetic mice induced by a high-fat and high-glucose diet. $\mathrm{p}<0.05$ compared to the normal group. ${ }^{* * *} \mathrm{p}<0.001$ compared to the normal group; ${ }^{\dagger} \mathrm{p}<0.05,{ }^{\dagger \dagger} \mathrm{p}<0.001$ compared to the control group.

pulverized by a homogenizer and centrifuged at $1,000 \mathrm{rpm}$. The supernatant was moved to a Zymo-Spin III Column, put in a 2-ml collection tube and centrifuged at 2,000 rpm for $60 \mathrm{~min}$. After adding $350 \mu 1$ of RNA wash buffer, the samples were centrifuged for $1 \mathrm{~min}$, washed twice and put in a $1.5-\mathrm{ml}$ collection tube. Finally, the samples were centrifuged at 1,000 rpm after adding $50 \mu \mathrm{l}$ of RNA-free water. The RNA which was extracted from this process was stored at $-70^{\circ} \mathrm{C}$ until analysis.

Reverse transcription-polymerase chain reaction (RT-PCR) of PPAR- $\alpha$, leptin, adiponectin and TNF- $\alpha$ mRNA in epididymal fat. To evaluate the expression levels of PPAR- $\alpha$, leptin, adiponectin and TNF- $\alpha$ mRNA, we performed semiquantitative RT-PCR. The reaction mixture, containing $1 \mu \mathrm{g}$ of RNA, PCR buffer, $5 \mathrm{mM}$ of $\mathrm{MgCl}_{2}, 1 \mathrm{mM}$ dNTP, 20 units of RNasin, $2.5 \mu \mathrm{M}$ Oligo(dT) and 100 units of Moloney murine leukemia virus reverse transcriptase, was incubated at $42^{\circ} \mathrm{C}$ for $50 \mathrm{~min}$, then heated at $70^{\circ} \mathrm{C}$ for $15 \mathrm{~min}$. PCR was carried out in an Eppendorf Mastercycler Gradient PCR device (Eppendorf, Hamburg, Germany). Each sample mixture contained PCR buffer, $2.5 \mathrm{mM}$ dNTP, 2 units of Taq polymerase and $5 \mathrm{pM}$ primers. The primers used were as follows: PPAR- $\alpha$, 5'-AATGGGCACTTCTAAGACTACCTG-3' and 5'-GTG CAGATTAGTTTTCAGGGATTT-3'; leptin, 5'-AGTGGG AATGAGAAATCACTTAGC-3' and 5'-GTGTATTGC TTTCCATCAAGTGTC-3'; adiponectin,5'-ACCTACGACCAG TATCAGGAAAAG-3' and 5'-ACTAAGCTGAAAGTGTGT CGACTG-3'; TNF- $\alpha$, 5'-TCTTCTCAAAATTCGAGTGAC AAG-3' and 5'-GAGAACCTGGGAGTAGACAAGGTA-3'; EF-1 $\alpha$ (housekeeping gene), 5'-CTCAGGTGATTATCCTGA ACCATC-3' and 5'-AACAGTTCTGAGACCGTT CTTCCA-3'. The PCR consisted of 33 cycles for PPAR- $\alpha$ at $59^{\circ} \mathrm{C}, 30$ cycles for leptin at $65^{\circ} \mathrm{C}, 25$ cycles for adiponectin at $59^{\circ} \mathrm{C}, 40$ cycles for TNF- $\alpha$ at $59^{\circ} \mathrm{C}$ and 25 cycles for EF- $1 \alpha$ at $58^{\circ} \mathrm{C}$. The expected PCR product sizes were 254 bp (for PPAR- $\alpha$ ), 212 bp (for leptin), $248 \mathrm{bp}$ (for adiponectin) and $180 \mathrm{bp}$ (for TNF- $\alpha$ ). The reaction products were subjected to densitometry after electrophoresis on a $2 \%$ agarose gel and stained with ethidium bromide. The amount of gene expression was quantified relative to EF-1 $\alpha$.

Statistical analysis. Statistical comparisons were performed using one-way analysis of variance (ANOVA) followed by 
Table I. Effects of Ephedra sinica on body weight change, food intake and epididymal fat in obese diabetic mice.

\begin{tabular}{|c|c|c|c|c|}
\hline & Normal & Control & Acarbose & Ephedra \\
\hline \multicolumn{5}{|l|}{ Body weight change (g) } \\
\hline Baseline & $31.4 \pm 1.17$ & $32.0 \pm 1.14$ & $31.5 \pm 1.43$ & $30.6 \pm 0.97^{\mathrm{d}}$ \\
\hline 1st week & $33.5 \pm 1.43^{\mathrm{d}}$ & $35.8 \pm 2.20^{\mathrm{a}}$ & $28.3 \pm 1.49^{\mathrm{c}, \mathrm{f}}$ & $25.9 \pm 1.20^{\mathrm{c}, \mathrm{f}}$ \\
\hline 2nd week & $34.6 \pm 1.71^{\mathrm{d}}$ & $36.9 \pm 2.96^{\mathrm{a}}$ & $30.4 \pm 2.07^{\mathrm{c}, \mathrm{f}}$ & $27.7 \pm 2.20^{\mathrm{c}, \mathrm{f}}$ \\
\hline 3rd week & $34.0 \pm 2.16^{\mathrm{f}}$ & $39.0 \pm 4.40^{c}$ & $30.9 \pm 2.73^{\mathrm{a}, \mathrm{f}}$ & $25.9 \pm 1.45^{\mathrm{c}, \mathrm{f}}$ \\
\hline 4 th week & $36.1 \pm 2.18^{d}$ & $39.8 \pm 2.70^{\mathrm{a}}$ & $32.8 \pm 3.19^{\mathrm{a}, \mathrm{f}}$ & $27.1 \pm 2.20^{\mathrm{c}, \mathrm{f}}$ \\
\hline 5 th week & $38.5 \pm 2.17^{\mathrm{d}}$ & $41.5 \pm 2.59^{a}$ & $34.4 \pm 3.20^{\mathrm{b}, \mathrm{f}}$ & $27.3 \pm 2.40^{\mathrm{c}, \mathrm{f}}$ \\
\hline 6th week & $38.4 \pm 0.84^{\mathrm{e}}$ & $42.3 \pm 2.67^{b}$ & $33.7 \pm 2.75^{\mathrm{c}, \mathrm{f}}$ & $28.7 \pm 2.60^{\mathrm{c}, \mathrm{f}}$ \\
\hline \multicolumn{5}{|l|}{ Food consumption } \\
\hline Food intake & $5.8 \pm 0.89$ & $5.1 \pm 0.92$ & $3.5 \pm 0.84^{\mathrm{b}, \mathrm{e}}$ & $5.4 \pm 0.97$ \\
\hline \multicolumn{5}{|l|}{ Epididymal } \\
\hline Grams & $0.57 \pm 0.16^{\mathrm{f}}$ & $1.19 \pm 0.45^{\mathrm{c}}$ & $0.44 \pm 0.18^{\mathrm{f}}$ & $0.47 \pm 2.21^{\mathrm{f}}$ \\
\hline Precentage of body weight & $1.50 \pm 0.44^{\mathrm{f}}$ & $3.05 \pm 1.15^{\mathrm{c}}$ & $1.14 \pm 0.47^{f}$ & $1.19 \pm 0.55^{\mathrm{f}}$ \\
\hline
\end{tabular}

Results are presented as the means \pm SD. Normal, normal diet-fed mice; control, Surwit's high-fat, high-fat diet-fed mice; acarbose, Surwit's high-fat and high-glucose diet containing acarbose-fed mice; Ephedra, Surwit's high-fat and high-glucose diet containing Ephedra-fed mice. ${ }^{\mathrm{a}} \mathrm{p}<0.05,{ }^{\mathrm{b}} \mathrm{p}<0.01,{ }^{\mathrm{c}} \mathrm{p}<0.001$ compared to the normal group; ${ }^{\mathrm{d}} \mathrm{p}<0.05,{ }^{\mathrm{e}} \mathrm{p}<0.01,{ }^{\mathrm{f}} \mathrm{p}<0.001$ compared to the control group.

Tukey's post hoc test using the GraphPad PRISM statistical package (version 4.03; GraphPad Software Inc., San Diego, CA, USA). All data are presented as the means \pm standard deviation (SD). All p-values are two-tailed, and significance was determined at $\mathrm{p}<0.05$.

\section{Results}

Surwit's high-fat, high-fat diet significantly increased body weight at week 6 in the control group compared to the normal group ( $42.3 \pm 2.67$ vs. $38.4 \pm 0.84 \mathrm{~g}, \mathrm{p}<0.01)$. This difference was present by the first week and was maintained to the completion of the study $(\mathrm{p}<0.05$ at weeks $1,2,4$ and $5, \mathrm{p}<0.01$ at week 6 , $\mathrm{p}<0.001$ at week 3) (Fig. 1, Table I). Body weight at week 6 was significantly reduced in the Ephedra group and the acarbose group compared to that of the control group $(33.7 \pm 2.75$, $42.3 \pm 2.67$ and $28.7 \pm 2.60 \mathrm{~g}$, for control, acarbose- and Ephedratreated groups, respectively; $\mathrm{p}<0.001)$. In the Ephedra group, body weight gain was significantly suppressed compared to the acarbose and the control groups $(\mathrm{p}<0.05$ at week $6, \mathrm{p}<0.01$ at weeks 1 and $2, \mathrm{p}<0.001$ at weeks 3,4 and 5 compared to the acarbose group, and $\mathrm{p}<0.001$ during all 6 weeks compared to the control group). The mean food consumption per day per mouse was decreased in the acarbose group compared to the other groups $(5.8 \pm 0.89,5.1 \pm 0.92,3.5 \pm 0.84$ and $5.4 \pm 0.97 \mathrm{~g}$ for normal, control, acarbose- and Ephedra-treated groups, respectively; $\mathrm{p}<0.01$, compared to the normal and control groups, p $<0.0001$ compared to the Ephedra group) (Table I). Food consumption was not reduced in the Ephedra group.

Surwit's high-fat, high-fat diet significantly increased the epididymal fat weight in the control group compared to the normal group $(1.19 \pm 0.45$ vs. $0.57 \pm 0.16 \mathrm{~g}, \mathrm{p}<0.001)$. Compared to the control group, Ephedra and acarbose reduced the epididymal fat weight $(1.19 \pm 0.45,0.44 \pm 0.18$ and $0.47 \pm 2.21 \mathrm{~g}$ for control, acarbose- and Ephedra-treated groups, respec- tively; $\mathrm{p}<0.001)$. The difference between the Ephedra and the acarbose groups was not significant. The ratio of the epididymal fat weight to the total body weight also decreased in the same manner (Table I).

Fasting blood glucose levels were measured at weeks 1, 3 and 6 . There were no differences among the groups at week 1 . Surwit's high-fat, high-fat diet increased fasting blood glucose levels in the control group compared to that of the normal group at week $3(79.7 \pm 13.0$ vs. $63.5 \pm 10.3 \mathrm{mg} / \mathrm{dl}, \mathrm{p}<0.01)$ and at week 6 $(82.8 \pm 18.2$ vs. $60.6 \pm 10.2 \mathrm{mg} / \mathrm{dl}, \mathrm{p}<0.01)$. Ephedra reduced fasting glucose compared to the control group at weeks 3 $(53.3 \pm 5.7$ vs. $79.7 \pm 13.0 \mathrm{mg} / \mathrm{dl}, \mathrm{p}<0.001)$ and $6(56.2 \pm 13.0 \mathrm{vs}$. $82.8 \pm 18.2 \mathrm{mg} / \mathrm{dl}, \mathrm{p}<0.001)$. However, in the acarbose group, fasting blood glucose was elevated compared to the normal group only at week $6(80.9 \pm 10.2$ vs. $60.6 \pm 10.2 \mathrm{mg} / \mathrm{dl}, \mathrm{p}<0.01)$ (Fig. 2, Table II).

An oral glucose test was carried out at week 6 . In the control group, blood glucose levels were elevated compared to the normal group at 0 and $60 \mathrm{~min}(82.8 \pm 18.2 \mathrm{vs} .60 .6 \pm 10.2 \mathrm{mg} / \mathrm{dl}$ at $0 \mathrm{~min}, \mathrm{p}<0.001 ; 216.6 \pm 50.8 \mathrm{vs} .165 .6 \pm 38.0 \mathrm{mg} / \mathrm{dl}$ at $60 \mathrm{~min}$, $\mathrm{p}<0.01)$. Ephedra reduced blood glucose levels compared to the control group at 0,30 and $60 \mathrm{~min}(56.2 \pm 13.0 \mathrm{vs}$. $82.8 \pm 18.2 \mathrm{mg} / \mathrm{dl} ; 56.2 \pm 13.0$ vs. $82.8 \pm 18.2 \mathrm{mg} / \mathrm{dl} ; 102.8 \pm 16.8$ vs. $216.6 \pm 50.8 \mathrm{mg} / \mathrm{dl}$ at 0,30 and $60 \mathrm{~min}$, respectively; $\mathrm{p}<0.001$ ). Acarbose reduced blood glucose levels compared to the control group only at $60 \mathrm{~min}(132.1 \pm 33.7 \mathrm{vs} .216 .6 \pm 50.8 \mathrm{mg} / \mathrm{dl}$, $\mathrm{p}<0.001$ ) (Fig. 2, Table II).

Total cholesterol (TC) was elevated only in the Ephedra group compared to the control group $(197.7 \pm 14.4 \mathrm{vs}$. $146.3 \pm 25.5 \mathrm{mg} / \mathrm{dl}, \mathrm{p}<0.001)$. Triglyceride (TG) was elevated in the control group compared to the normal group, but was reduced significantly in the Ephedra and the acarbose groups $(176.3 \pm 37.5,233.0 \pm 59.7,135.0 \pm 43.6$ and $129.6 \pm 28.1 \mathrm{mg} / \mathrm{dl}$ for normal, control, acarbose- and Ephedra-treated groups, respectively; $\mathrm{p}<0.05$ compared to the normal and acarbose 
Fasting Blood Glucose

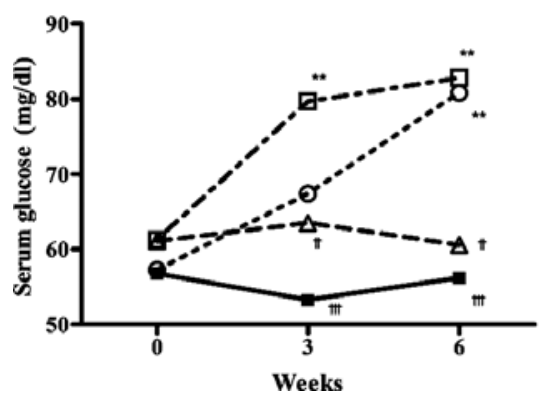

Oral Glucose Tolerance Test

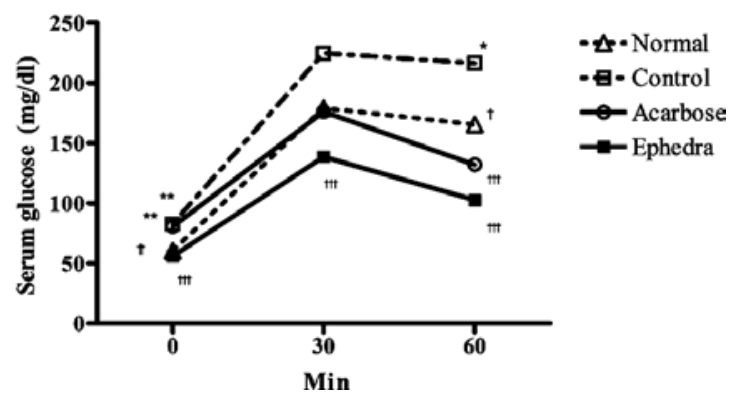

Figure 2. Effects of Ephedra sinica on (A) fasting glucose and (B) oral glucose tolerance test in obese diabetic mice induced by a high-fat and high-glucose diet. ${ }^{*} \mathrm{p}<0.05,{ }^{* *} \mathrm{p}<0.01$ compared to the normal group; ${ }^{\dagger} \mathrm{p}<0.05,{ }^{\dagger \dagger} \mathrm{p}<0.01,{ }^{\dagger \dagger} \mathrm{p}<0.001$ compared to the control group.

Table II. Effects of Ephedra sinica on biochemical parameters in obese diabetic mice.

\begin{tabular}{|c|c|c|c|c|}
\hline & Normal & Control & Acarbose & Ephedra \\
\hline \multicolumn{5}{|c|}{ Fasting blood glucose (mg/dl) } \\
\hline Week 1 & $61.1 \pm 9.80$ & $61.3 \pm 3.70$ & $57.3 \pm 13.60$ & $56.8 \pm 16.60$ \\
\hline Week 3 & $63.5 \pm 10.30^{\mathrm{e}}$ & $79.7 \pm 13.00^{\mathrm{b}}$ & $67.4 \pm 11.50$ & $53.3 \pm 5.70^{f}$ \\
\hline Week 6 & $60.6 \pm 10.20^{\mathrm{e}}$ & $82.8 \pm 18.20^{\mathrm{b}}$ & $80.8 \pm 10.20^{\mathrm{b}}$ & $56.2 \pm 9.70^{\mathrm{f}}$ \\
\hline \multicolumn{5}{|c|}{ Oral glucose tolerance test (mg/dl) } \\
\hline $0 \mathrm{~min}$ & $60.6 \pm 10.20^{\mathrm{e}}$ & $82.8 \pm 18.20^{\mathrm{b}}$ & $80.8 \pm 10.20^{\mathrm{b}}$ & $56.2 \pm 9.70^{\mathrm{f}}$ \\
\hline $30 \mathrm{~min}$ & $179.1 \pm 44.30$ & $224.6 \pm 66.20$ & $176.1 \pm 27.20$ & $138.6 \pm 18.50^{\mathrm{f}}$ \\
\hline $60 \mathrm{~min}$ & $165.6 \pm 38.00^{\mathrm{d}}$ & $216.6 \pm 50.80^{\mathrm{a}}$ & $132.0 \pm 33.70^{\mathrm{f}}$ & $102.8 \pm 16.80^{\mathrm{f}}$ \\
\hline \multicolumn{5}{|c|}{ Lipid profile (mg/dl) } \\
\hline Total cholesterol & $142.6 \pm 24.50$ & $146.3 \pm 25.50$ & $114.1 \pm 14.70$ & $197.7 \pm 14.40^{\mathrm{c}, \mathrm{f}}$ \\
\hline TG & $176.3 \pm 37.50^{\mathrm{a}}$ & $233.0 \pm 59.70$ & $135.0 \pm 43.60^{\mathrm{d}}$ & $129.6 \pm 28.10^{\mathrm{e}}$ \\
\hline HDL-cholesterol & $131.6 \pm 14.40$ & $109.1 \pm 29.50$ & $113.7 \pm 15.70$ & $149.9 \pm 22.20^{\mathrm{e}}$ \\
\hline TG/HDL ratio & $1.35 \pm 0.23^{\mathrm{f}}$ & $2.51 \pm 0.81^{\mathrm{c}}$ & $1.19 \pm 0.40^{\mathrm{f}}$ & $0.87 \pm 0.19^{\mathrm{f}}$ \\
\hline $\operatorname{AST}(\mathrm{mg} / \mathrm{dl})$ & $116.8 \pm 20.07$ & $133.12 \pm 30.12$ & $91.2 \pm 25.86^{\mathrm{d}}$ & $90.8 \pm 16.83^{\mathrm{d}}$ \\
\hline ALT (mg/dl) & $27.9 \pm 4.70^{\mathrm{f}}$ & $39.1 \pm 6.41^{c}$ & $23.9 \pm 4.81^{\mathrm{f}}$ & $25.1 \pm 4.38^{\mathrm{f}}$ \\
\hline
\end{tabular}

Results are presented as the means \pm SD. Normal, normal diet-fed mice; control, Surwit's high-fat and high-glucose diet-fed mice; acarbose, Surwit's high-fat and high-glucose diet containing acarbose-fed mice; Ephedra, Surwit's high-fat and high-glucose diet containing Ephedra-fed mice. AST, aspartate transaminase; ALT, alanine transaminase. ${ }^{\mathrm{a}} \mathrm{p}<0.05,{ }^{\mathrm{b}} \mathrm{p}<0.01,{ }^{\mathrm{c}} \mathrm{p}<0.001$ compared to the normal group; ${ }^{\mathrm{d}} \mathrm{p}<0.05$, ${ }^{\mathrm{e}} \mathrm{p}<0.01$, ${ }_{\mathrm{f}}^{\mathrm{p}}<0.001$ compared to the control group.

groups, $\mathrm{p}<0.01$ compared to the Ephedra group). High-density lipoprotein cholesterol (HDL) was reduced in the control group compared to the normal group, but the difference was not significant. By contrast, the Ephedra group demonstrated significantly elevated HDL levels compared to those of the normal and control groups $(131.6 \pm 14.4,109.1 \pm 29.5$ and $149.9 \pm 22.2 \mathrm{mg} / \mathrm{dl}$ for the normal, control and Ephedra-treated groups, respectively; $\mathrm{p}<0.01$ ). There was no significant difference in the acarbose group $(113.7 \pm 15.7 \mathrm{mg} / \mathrm{dl})$ compared to the others. Finally, the TG/HDL ratio was significantly elevated in the control group, but reduced in the Ephedra and acarbose groups $(1.35 \pm 0.23,2.51 \pm 0.81,1.19 \pm 0.40$ and $0.87 \pm 0.19$ for the normal, control, acarbose- and Ephedra-treated groups, respectively; $\mathrm{p}<0.001$ ) (Table II).

AST was elevated in the control group compared to the normal group $(133.12 \pm 30.12$ vs. $116.8 \pm 20.07 \mathrm{mg} / \mathrm{dl})$, but the difference was not statistically significant. However, Ephedra and acarbose reduced AST levels compared to the control group $(133.12 \pm 30.12,91.2 \pm 25.86$ and $90.8 \pm 16.83 \mathrm{mg} /$ dl for the control, acarbose- and Ephedra-treated groups, respectively; $\mathrm{p}<0.05$ ) (Table II). ALT was elevated in the control group compared to the normal group, but significantly reduced in the Ephedra and the acarbose groups $(27.9 \pm 4.70,39.1 \pm 6.41,23.9 \pm 4.81$ and $25.1 \pm 4.38 \mathrm{mg} / \mathrm{dl}$ for the normal, control, acarbose- and Ephedra-treated groups, respectively; $\mathrm{p}<0.001)$. There was no significant difference in ALT levels between the Ephedra group and the acarbose group (Table II).

Compared to the mRNA levels in the control group, the PPAR- $\alpha$ and adiponectin mRNA levels were significantly elevated by Ephedra treatment, while the TNF- $\alpha$ mRNA levels were reduced. The change in leptin mRNA levels was 


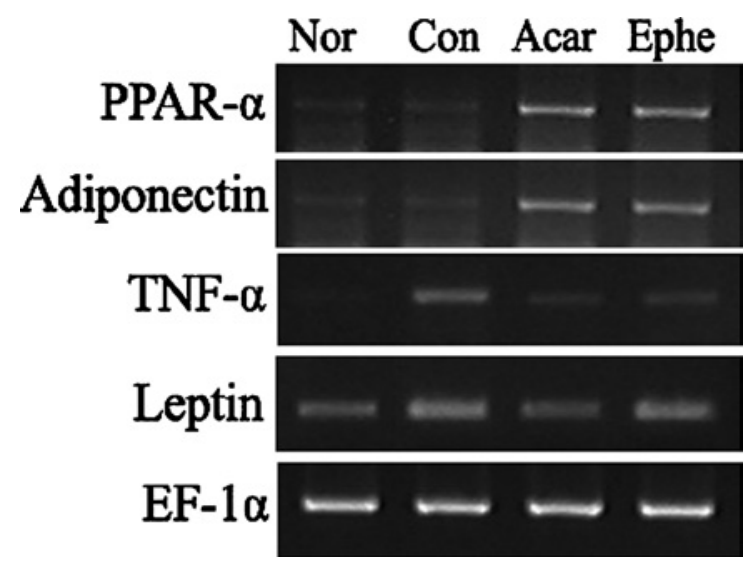

Figure 3. Effects of Ephedra sinica on the mRNA expression of PPAR- $\alpha$, adiponectin, TNF- $\alpha$ and leptin. Nor, normal; Con, control; Acar, mice fed acarbose; Ephe, mice fed ephedrine.

not significant (Fig. 3). Acarbose also elevated transcription of PPAR- $\alpha$ and adiponectin and caused a decrease in both TNF- $\alpha$ and leptin mRNA levels.

\section{Discussion}

Obesity is clearly associated with increased morbidity and mortality (10). However, in obesity-related type 2 diabetes, weight loss is difficult to achieve since most anti-diabetic drugs act by increasing weight $(11,12)$; therefore, the development of anti-obesity and anti-hyperglycemic strategies is of great importance.

Ephedra was found to promote weight loss in a healthy obese population (8), but its effects on and mechanisms involved in diet-induced obesity-related type 2 diabetes have not been clarified. The present study expands our understanding concerning the anti-obesity and anti-hyperglycemic effects of Ephedra under high-fat and high-glucose diets. We found that Ephedra suppressed weight gain for all 6 weeks of the study compared to the high-fat and high-glucose diet-fed control group, without food intake reduction. In parallel with the effects of Ephedra on body weight gain, epididymal fat weight and the ratio of the epididymal fat weight to the total body weight was also decreased. Furthermore, Ephedra improved insulin responsiveness. Ephedra reduced both fasting and post-prandial glucose levels, decreased TG, increased HDL and suppressed ALT elevation compared to the control group. In particular, Ephedra reduced weight gain and fasting glucose levels and improved HDL-cholesterol levels to a greater extent than was noted with acarbose treatment.

Acarbose is the first of a new class of anti-diabetic agents, the $\alpha$-glucosidase inhibitors (13). Acarbose reduces the post-prandial rise in plasma glucose and triglycerides, and decreases the toxic effects of glucose, thus delaying conversion of impaired glucose tolerance to diabetes $(12,13)$. Acarbose also prevents obesity, and the weight loss effects of acarbose may help delay the onset of diabetes $(12,13)$.

In this study, we used a high-fat and high-glucose diet-fed mouse model, which resulted in increased weight gain, stable hyperglycemia and insulin resistance (14). Furthermore, after just 1 week on the high-fat diet, baseline plasma glucose was significantly elevated (14). Additionally, the metabolic effi- ciency index was lower in mice fed a high-fat diet, and the weight gain observed in these mice cannot be fully explained by increased energy intake, but must also be the result of a reduced metabolic rate (14).

Obesity is traditionally defined as the presence of excessive body fat, and fat cells in obese individuals become dysfunctional for a number of reasons. One influencing factor is the development of large, insulin-resistant fat cells that lose their capacity to store triglycerides. Another problem is the infiltration of fat cells by cytokine-secreting macrophages, which results in low-grade inflammation and increased endoplasmic reticulum stress. In these adipocytes, there is decreased production of certain factors that are normally synthesized, such as adiponectin, while there is an accelerated release of other adipocytokines, such as TNF- $\alpha$ and leptin (15). In obesity-related disorders, PPAR- $\alpha$ holds a central role in the regulation of several key factors, including lipids, lipoprotein metabolism and inflammation (6).

Our findings showed that Ephedra reduced obesity and hyperglycemia by increasing the expression of PPAR- $\alpha$ and adiponectin, and reducing the expression of TNF- $\alpha$. PPAR- $\alpha$ has emerged as an important player in the convergence of obesity, diabetes and cardiovascular disease. PPAR- $\alpha$ is mainly expressed in tissues with a high degree of fatty acid metabolism, such as the liver and heart (16). Activation of PPAR- $\alpha$ improves regulation of fatty acid oxidation, inflammatory response and lipid and lipoprotein metabolism, including fatty acid uptake and $\beta$-oxidation. In this way, PPAR- $\alpha$ activation increases HDL-cholesterol and decreases TG levels, lipid accumulation and central obesity (6). Therefore, the use of PPAR- $\alpha$ activators, such as fibrates, offers the possibility of coordinated modification to repress inflammatory mechanisms with insulin-resistant conditions (6). To evaluate whether the effects of Ephedra on obesity-related type 2 diabetes were mediated by alterations in PPAR- $\alpha$ expression, we analyzed the mRNA levels of PPAR- $\alpha$. We found that PPAR- $\alpha$ expression was elevated; it is therefore likely that Ephedra decreased fat accumulation, weight gain and TG levels, and increased HDL-cholesterol levels by enhancing PPAR- $\alpha$.

Adiponectin, a 30-kDa adipokine with anti-diabetic properties similar to those of leptin, is expressed primarily in adipose tissue. Its concentrations exceed those of other adipokines by 100 -fold and are closely correlated to the amount of visceral fat (17). Adiponectin increases insulin sensitivity by increasing tissue fat oxidation which results in reduced circulating fatty acid levels and intracellular triglyceride content (18). Furthermore, adiponectin levels are independently predictive of HDL-cholesterol levels and glucose area beyond the contribution of visceral adiposity. Thus, adiponectin plays a central role as an anti-diabetic and anti-atherogenic adipokine (19). From the present study, it appears that Ephedra may improve glucose tolerance and HDL-cholesterol levels by elevating adiponectin mRNA expression.

An important recent development in our understanding of obesity has been the emergence of the concept that obesity with diabetes is characterized by a state of chronic low-grade inflammation (4). TNF- $\alpha$, a powerful local regulator within adipose tissue, contributes to insulin resistance and inflammation (4). TNF- $\alpha$ is overexpressed in adipose tissue and is reduced by weight loss (20). It has also been found that 
high TNF- $\alpha$ impairs insulin-mediated whole-body glucose disposal and insulin-stimulated suppression of hepatic glucose output (21). Similarly, TNF- $\alpha$ mRNA expression was elevated in the control group and reduced by Ephedra and acarbose treatments, which mediated the improvement of insulin responsiveness and the reduction of weight gain.

Based on these results, we conclude that Ephedra reduced weight gain and improved hyperglycemia in mice with obesityrelated glucose intolerance induced by high-fat feeding. Our findings suggest that these anti-obesity and anti-hyperglycemic effects of Ephedra could be mediated by the elevated expression of PPAR- $\alpha$ and adiponectin and the suppression of TNF- $\alpha$ expression.

\section{Acknowledgements}

This study was supported by the Kyung Hee University Research Fund in 2010 (KHU-2010-0676).

\section{References}

1. Costacou T and Mayer-Davis EJ: Nutrition and prevention of type 2 diabetes. Annu Rev Nutr 23: 147-170, 2003.

2. Kahn BB and Flier JS: Obesity and insulin resistance. J Clin Invest 106: 473-481, 2000.

3. Bray GA and Bellanger T: Epidemiology, trends, and morbidities of obesity and the metabolic syndrome. Endocrine 29: 109-117, 2006.

4. Trayhurn P and Wood IS: Adipokines: inflammation and the pleiotropic role of white adipose tissue. Br J Nutr 92: 347-355, 2004.

5. Maeda N, Takahashi M, Funahashi T, et al: PPARgamma ligands increase expression and plasma concentrations of adiponectin, an adipose-derived protein. Diabetes 50: 2094-2099, 2001.

6. Fruchart JC: Peroxisome proliferator-activated receptor-alpha (PPARalpha): at the crossroads of obesity, diabetes and cardiovascular disease. Atherosclerosis 205: 1-8, 2009.

7. Abourashed EA, El-Alfy AT, Khan IA and Walker L: Ephedra in perspective - a current review. Phytother Res 17: 703-712, 2003.
8. Shekelle PG, Hardy ML, Morton SC, et al: Efficacy and safety of ephedra and ephedrine for weight loss and athletic performance: a meta-analysis. JAMA 289: 1537-1545, 2003.

9. Hackman RM, Havel PJ, Schwartz HJ, et al: Multinutrient supplement containing ephedra and caffeine causes weight loss and improves metabolic risk factors in obese women: a randomized controlled trial. Int J Obes (Lond) 30: 1545-1556, 2006.

10. Higgins M, D'Agostino R, Kannel W, Cobb J and Pinsky J: Benefits and adverse effects of weight loss. Observations from the Framingham Study. Ann Intern Med 119: 758-763, 1993.

11. Nilsson PM: Is weight loss beneficial for reduction of morbidity and mortality? What is the controversy about? Diabetes Care 31 (Suppl 2): 278-283, 2008.

12. Chiasson JL, Josse RG, Gomis R, et al: Acarbose for prevention of type 2 diabetes mellitus: the STOP-NIDDM randomised trial. Lancet 359: 2072-2077, 2002.

13. Hanefeld M: The role of acarbose in the treatment of non-insulindependent diabetes mellitus. J Diabetes Complications 12: 228-237, 1998.

14. Winzell MS and Ahren B: The high-fat diet-fed mouse: a model for studying mechanisms and treatment of impaired glucose tolerance and type 2 diabetes. Diabetes 53 (Suppl 3): 215-219, 2004.

15. Ioannidis I: The road from obesity to type 2 diabetes. Angiology 59: S39-S43, 2008.

16. Braissant O, Foufelle F, Scotto C, Dauca M and Wahli W: Differential expression of peroxisome proliferator-activated receptors (PPARs): tissue distribution of PPAR-alpha, -beta, and -gamma in the adult rat. Endocrinology 137: 354-366, 1996.

17. Dyck DJ: Adipokines as regulators of muscle metabolism and insulin sensitivity. Appl Physiol Nutr Metab 34: 396-402, 2009.

18. Diez JJ and Iglesias P: The role of the novel adipocyte-derived hormone adiponectin in human disease. Eur J Endocrinol 148: 293-300, 2003

19. Yamauchi T, Nio Y, Maki T, et al: Targeted disruption of AdipoR1 and AdipoR2 causes abrogation of adiponectin binding and metabolic actions. Nat Med 13: 332-339, 2007.

20. Ziccardi P, Nappo F, Giugliano G, et al: Reduction of inflammatory cytokine concentrations and improvement of endothelial functions in obese women after weight loss over one year. Circulation 105: 804-809, 2002.

21. Londos C, Brasaemle DL, Schultz CJ, et al: On the control of lipolysis in adipocytes. Ann NY Acad Sci 892: 155-168, 1999. 